\title{
水溶液を反応場としたビスマス鉄複合酸化物の生成と粒子特性
}

\author{
堀部 正吉々1, 山本 直一个2 \\ 1 1 京都大学総合人間学部, $=$ 606-8501 京都市左京区吉田二本町. \\ 42 京都大学大学院 - 人間 - 環境学研究科, $\overline{0}$ 606-8501 京都市左京区吉田二本松町.
}

\section{The Formation of $(\mathrm{Bi}-\mathrm{Fe})$ Complex Oxides and the Characterization of the Obtained Particles}

\author{
Masayoshi Horibe ${ }^{\text {4r } 1}$ and Naoichi Yamamoto ${ }^{\text {t32 }}$ \\ 41 1 Faculty of Integrated Human Studies, Kyoto University, Yoshida-nihonmatsucho Sakyo-ku, Kyoto 606-8501. \\ $4^{2}$ Graduate School of Human and Environmental Studies, Kyoto University, Yoshida-nihonmatsucho Sakyo-ku, Kyoto 606-8501.
}

Received January 21, 2003

\begin{abstract}
SYNOPSIS
The formation diagram of $\mathrm{Bi}-\mathrm{Fe}-\mathrm{OH}^{-}$system in the aqueous solution was studied using hydrothermal or "wet" method. Three kinds of bismuth-ferric oxides, $\mathrm{Bi}_{25} \mathrm{FeO}_{40}$ ( $\mathrm{Fe}$-sillenite), $\mathrm{BiFeO}_{3}$, and $\mathrm{Bi}_{2} \mathrm{Fe}_{4} \mathrm{O}_{9}$ were obtained depending on their reaction conditions. The stoichiometric $\mathrm{Bi}_{25} \mathrm{FeO}_{40}$ has two kinds of particle shapes, the cubic and the tetrahedral, depend on its reaction conditions, although formation mechanism of the two kinds of particle shapes is not clear yet. The precipitate obtained below $100^{\circ} \mathrm{C}$ from starting materials with higher ratio of $\mathrm{Fe} / \mathrm{Bi}$ than 3.8 mole $\%$ showed interesting feature as follows. The precipitate gave only analogous XRD spectrum of $\mathrm{Bi}_{25} \mathrm{FeO}_{40}$, but observations by SEM and Mossbauer effect showed the surface of the precipitate was coated homogenously with fine particles of amorphous $\mathrm{Fe}$ oxide. The $\mathrm{Bi}_{25} \mathrm{FeO}_{40}$ coated with amorphous fine particles of Fe oxide (hereafter described as pseudo Fe-sillenite) reacted with $\mathrm{CO}_{2}$ gas or $\mathrm{CO}_{3}^{2-}$ in aqueous solution and easily converted to $\mathrm{Bi}_{2} \mathrm{O}_{2}\left(\mathrm{CO}_{3}\right)$ at the mild reaction conditions. The gradual conversion took place even at the room temperature during the prolonged period. The phenomena may be applied to the immobilization of the $\mathrm{CO}_{2}$ in the air and in the aqueous solution.
\end{abstract}

KEY WORDS

Hydrothermal, $\mathrm{Bi}_{25} \mathrm{FeO}_{40}, \mathrm{BiFeO}_{3}, \mathrm{Bi}_{2} \mathrm{Fe}_{4} \mathrm{O}_{9}, \mathrm{Bi}_{2} \mathrm{O}_{2} \mathrm{CO}_{3}, \mathrm{CO}_{2}$ immobilization

\section{1 緒言}

水溶液を反応場とした酸化物合成法はその特長を生かした 数多くの研究がこれまでに報告されている.その特徵の一つ に通常セラミック合成に用いられる焼結法に比較してより稳 和な反応条件下での合成が可能なことが挙げられる.またそ の生成過程も，原料の水溶液中への溶解及び再析出あるいは 水溶液中のイオンのインターカレーション, デインターカ レーション等の焼結法とは異なったプロセスを経るため,生 成物が特異な粒子形態を示すことも多い，本報告者等は， 様々なビスマス複合化合物の合成に，水溶液を反応場とした 合成法を応用し，新規化合物の合成あるいは新規合成プロセ スの開発を試みている．その中でもビスマスと遷移金属イオ ンを含む複合酸化物には数多くの種類が知られており，金属 イオンの種類, 結晶構造等に依存した様々な物性を示す.遷移 金属イオンが鉄の場合には,ビスマス鉄複合酸化物としては $\mathrm{Bi}_{25} \mathrm{FeO}_{40}, \mathrm{Bi}_{46} \mathrm{Fe}_{2} \mathrm{O}_{72}{ }^{* 1)}, \mathrm{Bi}_{36} \mathrm{Fe}_{2} \mathrm{O}_{57}, \mathrm{BiFeO}_{3}, \mathrm{Bi}_{2} \mathrm{Fe}_{4} \mathrm{O}_{9}$ などの組成
を持つ酸化物が報告されている。なお $\mathrm{Bi}_{25} \mathrm{FeO}_{40}$ は sillenite 構 造と呼ばれる同じ結晶構造を持つ一群の化合物に属し，しば しばFe-silleniteと呼ばれている。

この他に $\mathrm{Bi}_{3.43} \mathrm{Fe}_{0.57} \mathrm{O}_{6}$ や $\mathrm{Bi}_{24} \mathrm{Fe}_{2} \mathrm{O}_{39}$ などのように, 組成的に は $\alpha-\mathrm{Bi}_{2} \mathrm{O}_{3}$ の $\mathrm{Bi}$ の一部が $\mathrm{Fe}$ で置換した組成を持つ準安定相の 酸化物も報告されている. 通常は安定相の合成は $\alpha-\mathrm{Bi}_{2} \mathrm{O}_{3}$ と $\alpha-\mathrm{Fe}_{2} \mathrm{O}_{3}$ を $\mathrm{Bi}$ と $\mathrm{Fe}$ の比が所定の比になるように混合し, 大気雾 囲気の下で焼結合成法により得られる ${ }^{1}$.水溶液を反応場とした ビスマス鉄酸化物の合成は, 1990年にS. Radaev, L. Muradyan and $\mathrm{Yu}$. Karginにより $\mathrm{Bi}_{25} \mathrm{FeO}_{40}$ 単結晶の構造解析が報告されて いるが,この報告書の中で解析に用いた試料はS. Fedotovにより 水熱法により合成されたと述べられている。この他にsillenite相 の合成について, 1985 年に A. Ramanan and J. Gopalakirishanan による水溶液中の低温での Me-sillenite $(\mathrm{Me}=\mathrm{Mn}, \mathrm{Fe}, \mathrm{Co})$ の合

\footnotetext{
*1) $\mathrm{Bi}_{36} \mathrm{Fe}_{2} \mathrm{O}_{57}$ は $\mathrm{Bi}_{23} \mathrm{FeO}_{40}$ と同し化合物であることが $\mathrm{Bi}_{2} \mathrm{FeO}_{40}$ の結晶構造解析を遂行した研究 者により指摘されている。
} 
成報告がある ${ }^{2)}$ 。この報告は $\mathrm{Bi}_{25} \mathrm{FeO}_{40}$ および $\mathrm{Bi}_{115.5} \mathrm{Fe}_{145} \mathrm{O}_{39}$ の 2 種類の組成を持つ Fe-sillenite 相の生成を述べている。 また $\mathrm{Co}$ については $\mathrm{Bi}_{25} \mathrm{CoO}_{40}$ および $\mathrm{Bi}_{95} \mathrm{Co}_{16.5} \mathrm{O}_{38}, \mathrm{Mn}$ については $\mathrm{Bi}_{13} \mathrm{Mn}_{13} \mathrm{O}_{40}$ の組成をもつ sillenite相の存在を報告している。し かしながら $\mathrm{Bi}_{25} \mathrm{FeO}_{40}$ 相以外の相の存在については現在まで確 定されているとは言いがたい。

本論文は，ビスマス鉄複合酸化物の水溶液を反応場とした 生成物について検討を行い，更に $\mathrm{Bi}-\mathrm{Fe}-\mathrm{OH}^{-}$系に於いて，反 応温度が $100^{\circ} \mathrm{C}$ 以下で $\mathrm{Fe} / \mathrm{Bi}$ の出発時の仕込量が $3.8 \mathrm{~mol} \%$ 以 上の反応条件下で得られた, $\mathrm{Bi}_{25} \mathrm{FeO}_{40}$ (空間群 123 ) と同じXRD パターンを与える擬 Fe-sillenite の沈殿の特異な粒子形態と， この粒子を用いた $\mathrm{CO}_{2}$ の固定化の可能性について報告する.

\section{2 実験方法}

出発原料としては $\mathrm{Bi}\left(\mathrm{NO}_{3}\right)_{3} \cdot 5 \mathrm{H}_{2} \mathrm{O}$ (試薬特級，和研薬)およ び $\mathrm{Fe}\left(\mathrm{NO}_{3}\right)_{3} \cdot 6 \mathrm{H}_{2} \mathrm{O}$ (試薬特級, 和研莧) を用い，必要に応じて $\alpha-\mathrm{Bi}_{2} \mathrm{O}_{3}$ (試薬特級，和研薬) および $\alpha-\mathrm{FeOOH}$ を出発原料と して使用した.

高温領域; 反応温度 $=300 \sim 600^{\circ} \mathrm{C}$ ではテストチューブ型の 高圧反応容器を用い, 所定量のビスマスおよび鉄の出発原料 を銀チューブ中に過剩のアルカリ溶液と共に封入後，所定の 温度で圧力 $=1500 \mathrm{~kg} / \mathrm{cm}^{2}$, 反応時間 $=150 \mathrm{~h}$, 保持した後室温 まで急冷した。なおこの温度領域では出発原料として $\mathrm{Bi}\left(\mathrm{NO}_{3}\right)_{3} \cdot 5 \mathrm{H}_{2} \mathrm{O}$ と $\mathrm{Fe}\left(\mathrm{NO}_{3}\right)_{3} \cdot 6 \mathrm{H}_{2} \mathrm{O}$ の組み合わせと $\alpha-\mathrm{Bi}_{2} \mathrm{O}_{3}$ と $\alpha$ -FeOOH の組み合わせで生成物に差が生じないことを確認し たのち，主として後者の組み合わせを用いた．

中温領域; 反応温度 $=100 \sim 280^{\circ} \mathrm{C}$ では蓋付きのテフロン管

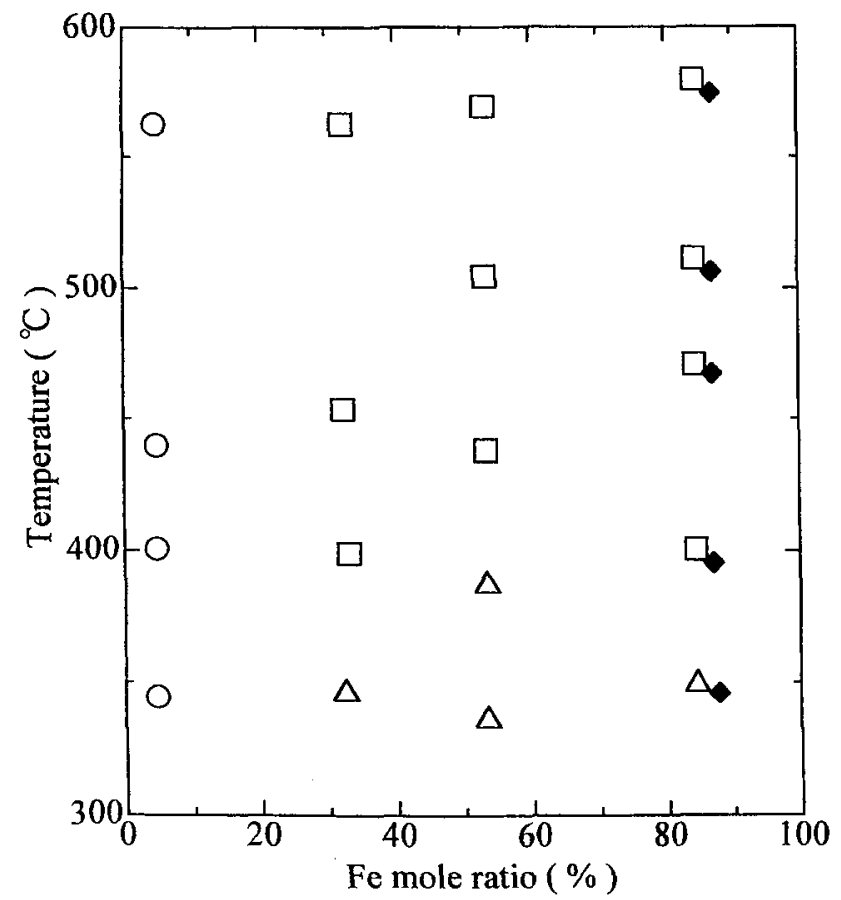

Fig.1 Formation diagram of $\mathrm{Bi}-\mathrm{Fe}-\mathrm{OH}^{-}$system between 300 to $600^{\circ} \mathrm{C} . \bigcirc \mathrm{Bi}_{25} \mathrm{FeO}_{40}, \triangle \mathrm{BiFeO}_{3}, \square \mathrm{Bi}_{2} \mathrm{Fe}_{4} \mathrm{O}_{9}$ and $\alpha-\mathrm{Fe}_{2} \mathrm{O}_{3}$
$(30 \phi \times 200 \mathrm{~mm})$ 中に, $\mathrm{Bi}\left(\mathrm{NO}_{3}\right)_{3} \cdot 5 \mathrm{H}_{2} \mathrm{O}$ と $\mathrm{Fe}\left(\mathrm{NO}_{3}\right)_{3} \cdot 6 \mathrm{H}_{2} \mathrm{O}$ を所定 の混合比に調整した出発原料および反応場となるアルカリ水 溶液を挿入しこれを靜置式モーレー型オートクレーブ中に 入れ一定時間所定の温度で反応させた. 圧力は平衡自然圧で ある。

低温領域; 反応温度 $=30 \sim 80^{\circ} \mathrm{C}$ では所定量の出発原料を所 定の濃度のアルカリ水溶液 $10 \mathrm{~m} l$ と共にガラスアンブル容器に 入れ, このガラスアンプル容器を恒温振とう槽に浸して, 反 応時間 $=24 \mathrm{~h}$ で保持した。

いずれの領域に於いても，アルカリ水溶液は反応に適する $\mathrm{OH}^{-}$濃度の水溶液の反応場を保持するために, 0.4 10M- $\mathrm{NaOH}$ 水溶液あるいは $\mathrm{KOH}$ 水溶液を使用した。得られた生成物はろ 過，水洗，乾燥の後XRDにより同定した後，評価に供した。

\section{3 結果及び考察}

\section{1 生成図}

水溶液を反応場とした $\mathrm{Bi}$ 系酸化物の合成反忘では, 水溶液 か酸性の場合は，Bi と Oのみによる酸化物ではなく，溶液中 に存在する陰イオンあるいは陰イオン基を結晶中に取り込ん だ塩基性複合酸化物を生成する.塩基性複合酸化物の生成を 避けるため, 本実験は塩基性複合酸化物が生成せず $\alpha-\mathrm{Bi}_{2} \mathrm{O}_{3}$ の みが生成する，アルカリ性水溶液を反応場としてもちいた。 Fig.1 に高温領域の生成図を示す.この領域では端成分の $\alpha-$ $\mathrm{Bi}_{2} \mathrm{O}_{3}$ と $\alpha-\mathrm{Fe}_{2} \mathrm{O}_{3}$ の他に，化学量論的組成で $\mathrm{Bi}_{2} \mathrm{FeO}_{40}$ が，また $\mathrm{Bi}_{2} \mathrm{Fe}_{4} \mathrm{O}_{9}$ が $400^{\circ} \mathrm{C}$ 以上で, $\mathrm{BiFeO}_{3}$ が $400^{\circ} \mathrm{C}$ 以下で生成する ことがあきらかとなった. Fig.2に中温および低温領域の生成

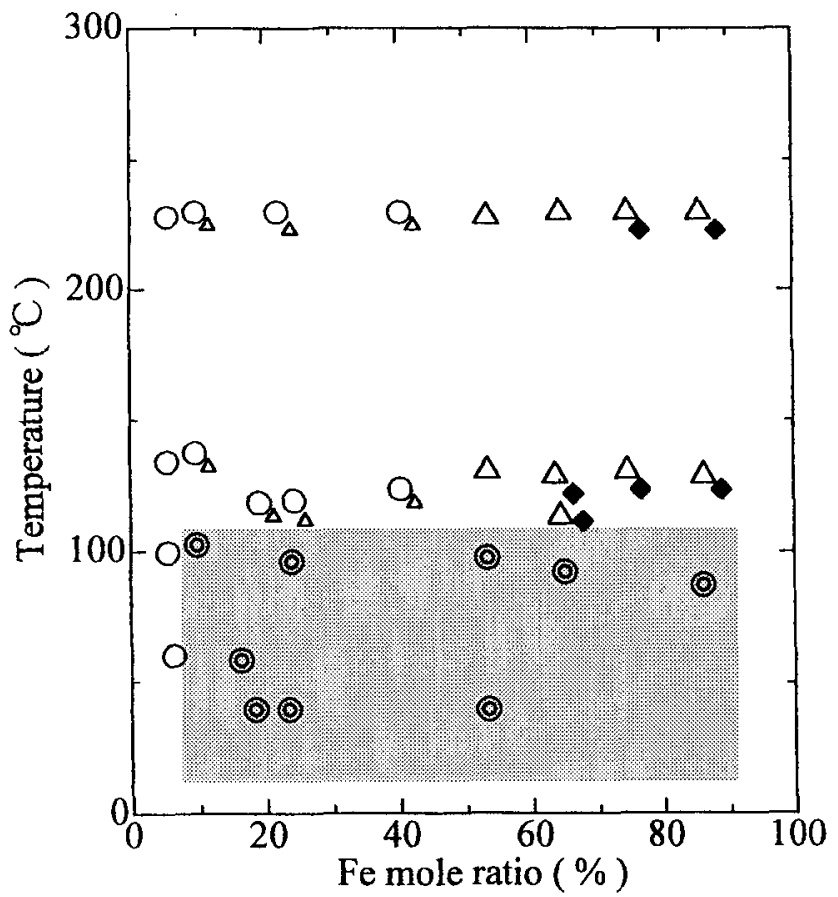

Fig.2 Formation diagram of the precipitate obtained in $\mathrm{Bi}-\mathrm{Fe}-\mathrm{OH}^{-}$ system 30 to $100^{\circ} \mathrm{C}$. Halftone dot meshing shows the area where pseudo $\mathrm{Fe}$-sillenite precipitates. $\bigcirc \mathrm{Bi}_{25} \mathrm{FeO}_{40}$, () pseudo $\mathrm{Fe}$-sillenite, $\triangle \mathrm{BiFeO}_{3}, \square \mathrm{Bi}_{2} \mathrm{Fe}_{4} \mathrm{O}_{9}$ and $\diamond \alpha-\mathrm{Fe}_{2} \mathrm{O}_{3}$ 


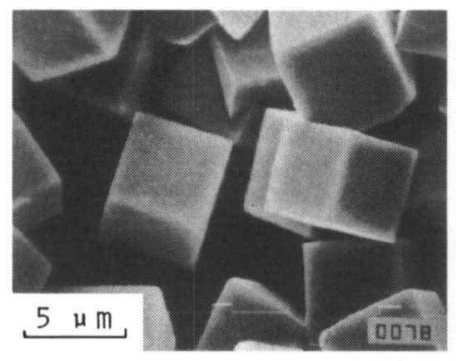

(a)

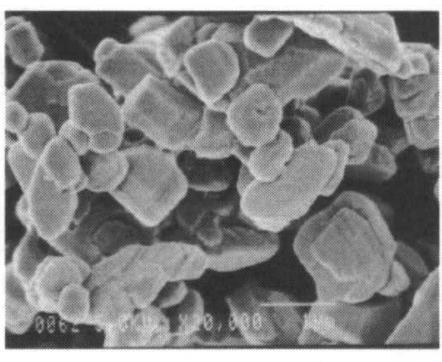

(b)

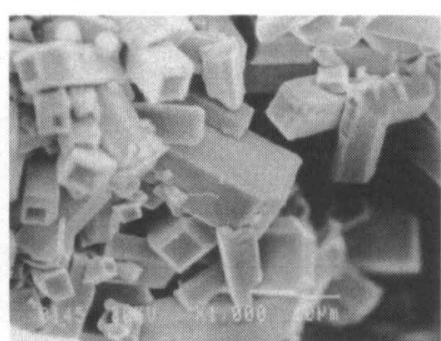

(c)

Fig.3(a) (c) The particle shapes of (a) $\mathrm{Bi}_{25} \mathrm{FeO}_{40}$, (b) $\mathrm{BiFeO}_{3}$ and (c) $\mathrm{Bi}_{2} \mathrm{Fe}_{4} \mathrm{O}_{9}$.

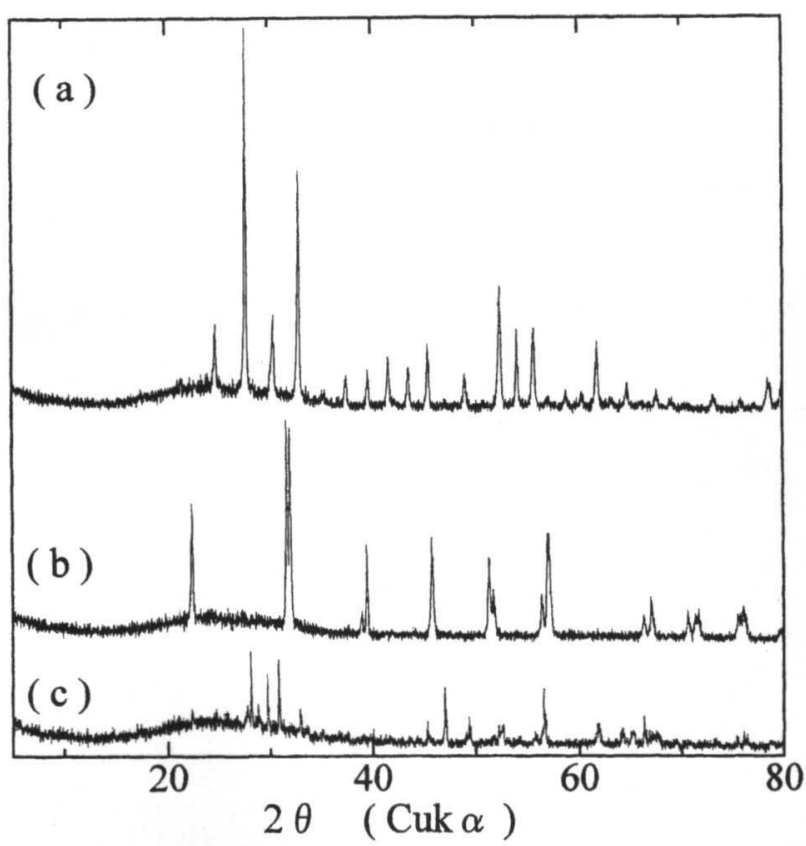

Fig.4(a) (c) The XRD patterns of (a) $\mathrm{Bi}_{25} \mathrm{FeO}_{40}$, (b) $\mathrm{BiFeO}_{3}$ and (c) $\mathrm{Bi}_{2} \mathrm{Fe}_{4} \mathrm{O}_{9}$.

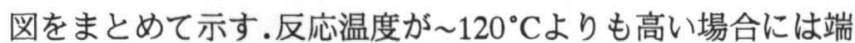
成分の他に $\mathrm{Bi}_{25} \mathrm{FeO}_{40}, \mathrm{BiFeO}_{3}$ が単相として得られる. Fig.3(a) 〜 (c) および Fig.4(a) (c) に得られた BiFe 複合酸化物の SEM 写真およびXRDパターンを示す. 各化合物はいずれも特有の 粒子形状をもっている. 温度が $100^{\circ} \mathrm{C}$ 以上では, 仕込み量の $\mathrm{Bi} / \mathrm{Fe}$ 比が各々の単相成分比からずれている組成領域では, 平 衡状態図と同様に 2 種類の単相の混合物が生成している。 し かしながら温度が $100^{\circ} \mathrm{C}$ より低くなると, $\mathrm{BiFeO}_{3}$ の生成は 観測されなくなる. 代わって FeのBiに対する仕込みが 3.8 $80 \mathrm{~mole} \%$ の極めて広範囲な組成領域で(Fig.2の網掛け領域)で $\mathrm{Bi}_{25} \mathrm{FeO}_{40}$ とまったく同じXRDパターンを示す沈殿が生成する (この沈殿を便宜上, 擬Fe-sillenite 呼ぶ). 一例として Fig.5 (a) $\sim(\mathrm{e})$ に $\mathrm{Bi}_{25} \mathrm{FeO}_{40}$ および仕込み量の $\mathrm{Fe} / \mathrm{Bi}$ の mole 比が 3.8 の $\mathrm{Fe}-$ sillenie および 3.8 50\% までの擬Fe-sillenite の XRD パターン を示す. XRDパターンから求められる格子定数は実験精度の 範囲では, $\mathrm{Bi}$ と Feの仕込み量の比に依存せず, 全ての場合に

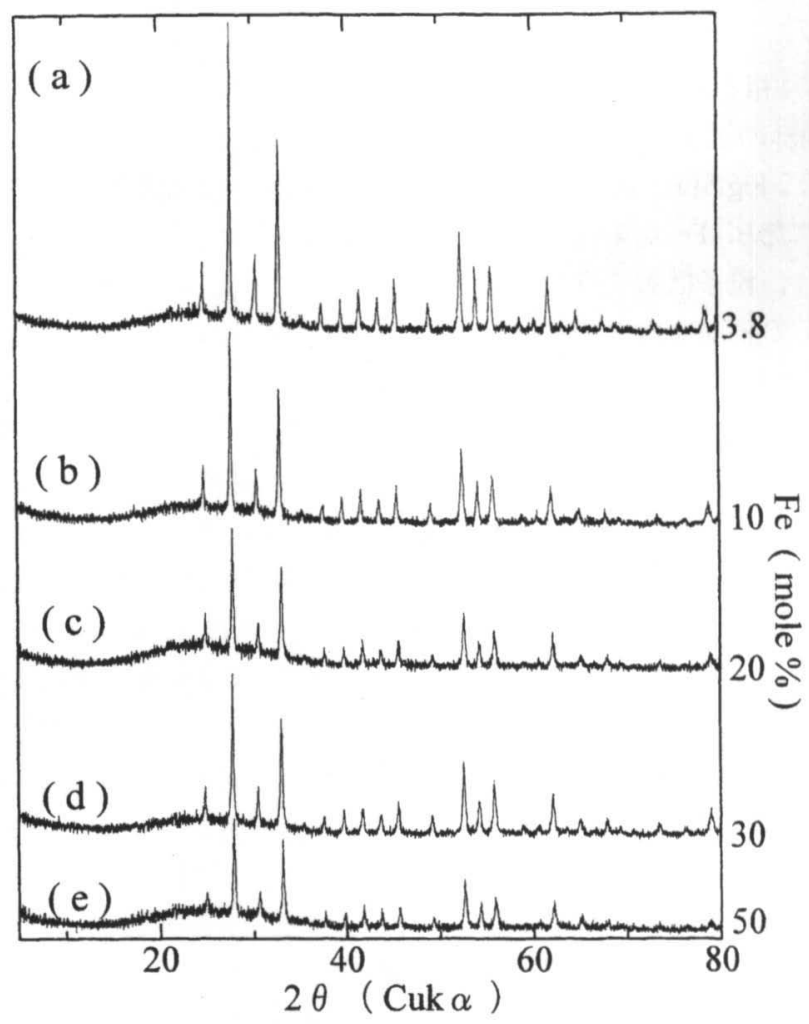

Fig.5 (a) (e) The XRD patterns of (a) $\mathrm{Bi}_{25} \mathrm{FeO}_{40}$, (b) pseudo $\mathrm{Fe}$ sillenite $(\mathrm{Fe} / \mathrm{Bi}=10$ mole \%), (c) pseudo Fe-sillenite ( $\mathrm{Fe} / \mathrm{Bi}=20$ mole \%), (d) pseudo $\mathrm{Fe}$-sillenite $(\mathrm{Fe} / \mathrm{Bi}=$ $30 \mathrm{~mole} \%$ ) and (e) pseudo $\mathrm{Fe}$-sillenite $(\mathrm{Fe} / \mathrm{Bi}=50$ mole \%). The $\mathrm{Fe} / \mathrm{Bi}$ ratio in the parenthesis is the starting ratio of $\mathrm{Fe}$ and $\mathrm{Bi}$ materials.

一定值 $\mathrm{a}=1.0913 \mathrm{~nm}$ を示す. XRD パターン同定の結果より求 められた擬 Fe-sillenite 生成領域を E. M. Levin and R. S. Roth により与えられた状態図のsillenite構造を持つ化合物の生成領 域と比較すると大きな違いが見られる. E. M. Levin and R.S. Rothの結果はsillenite構造を持つ BiFe複合酸化物 (Fe-sillenite) の組成は $\mathrm{Bi}_{25} \mathrm{FeO}_{40}$ で殆ど固溶領域を持たない. それに対して 今回の実験で得られた XRD 的に sillenite 構造 1 相を示す沈殿 (擬Fe-sillenite)は, 見かけ上極めて広い固溶領域をもつ.この 原因を明らかにするため, XRDパターンはいずれも $\mathrm{Bi}_{25} \mathrm{FeO}_{40}$ 


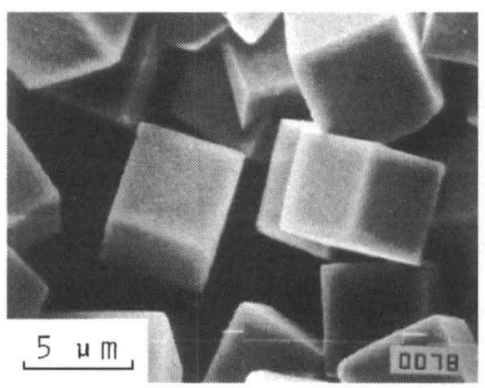

(a)

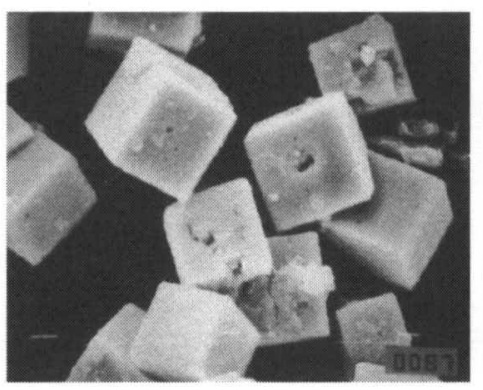

(b)

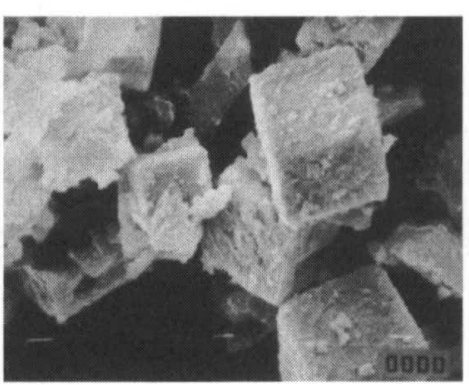

(c)

Fig.6(a) (c) The SEM photographs of stoichiometric and pseudo Fe-sillenite particles. (a) $\mathrm{Bi}_{25} \mathrm{FeO} \mathrm{O}_{40}(\mathrm{Fe} / \mathrm{Bi}=3.8$ mole\%), (b) pseudo $\mathrm{Fe}$-sillenite $(\mathrm{Fe} / \mathrm{Bi}=10.6 \mathrm{~mole} \%)$, and (c) pseudo $\mathrm{Fe}-$ sillenite $(\mathrm{Fe} / \mathrm{Bi}=23.0 \mathrm{~mole} \%)$.

の1相を示しているが, Feの仕込み量をそれぞれ3.8, 10.6, 23.0 mole\%と変化させて得られた沈殿粒子のSEM観察をおこなつ た. Fig.6(a) (c)に観測された粒子を示す. 状態図から求めら れた $\mathrm{Bi}_{25} \mathrm{FeO}_{40}$ の組成に対応する $3.8 \mathrm{~mole} \%$ の $\mathrm{Fe}$ 仕込み量の場 合，粒子は数ミクロンの大きさを持つ立方体の形状を持ち, その表面は均一で平滑である.ところが $\mathrm{Fe}$ の仕込み量のモル 比が 10.6, 23 mole\% と増大するにつれて, 全体的な立方体の 形状は保たれているが, 表面には亀裂がはいったようになり, 細かい不定形の沈殿で不規則におおわれてくる.この傾向は $\mathrm{Fe}$ の量が増大するに従って顕著となってくる (この微細な不 定形の沈殿の部分は EPMA-EDX の測定の結果より Fe 含有量 が極めて多いことが確認されている ). 擬 Fe-sillenite 中の Fe のメスバウワー効果を室温で観測した結果,4重極能率による 分裂を示す常磁性状態のスペクトルが観測された.一例とし て Fig.7(a),(b)にそれぞれ $\mathrm{Bi}_{25} \mathrm{FeO}_{40}$ と仕込み時の $\mathrm{Fe}$ のモル比 が60\%の場合のスペクトルを示す (eqQ $=0.56 \mathrm{~mm} / \mathrm{s}$, isomer shift $=0.30 \mathrm{~mm} / \mathrm{s})$. 反応後の滤液中の溶存 $\mathrm{Fe}$ イオン量を蛍光 $\mathrm{X}$ 線分 析法(ウルトラトレースシステム理学電機 K.K.) を用いて測定 した結果, 実験の誤差範囲で Feイオンは検出されなかった. 従ってすべてのFeはなんらかの形で沈殿となっていると考え られる. またSQUIDによる磁化率の測定は極めて興味深い挙
動を示す. Fig.8(a),(b)に $\mathrm{Bi}_{25} \mathrm{FeO}_{40}$ と仕込み時の $\mathrm{Fe}$ のル比が $50 \%$ の擬-sillenite相の(1相と仮定した)磁化率を示す. $\mathrm{Bi}_{25} \mathrm{FeO}_{40}$ の磁化率は測定領域全体で常磁性的挙動を示す.この結果は

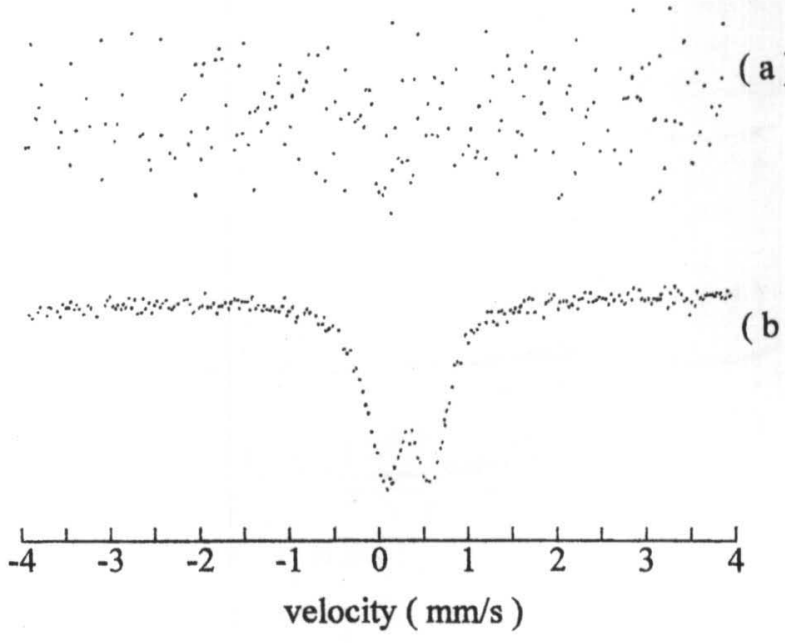

Fig.7 The Mossbauer spectrum of (a) $\mathrm{Bi}_{25} \mathrm{FeO}_{40}$ (no explicit spectrum was observed because of poor $\mathrm{Fe}$ content) and (b) pseudo $\mathrm{Fe}$-sillenite $(\mathrm{Fe} / \mathrm{Bi}=60.0 \mathrm{~mole} \%), \mathrm{IS}=0.30 \mathrm{~mm} / \mathrm{s}$ and $\mathrm{eq} \mathrm{Q}=0.56 \mathrm{~mm} / \mathrm{s}$ at the room temperature.
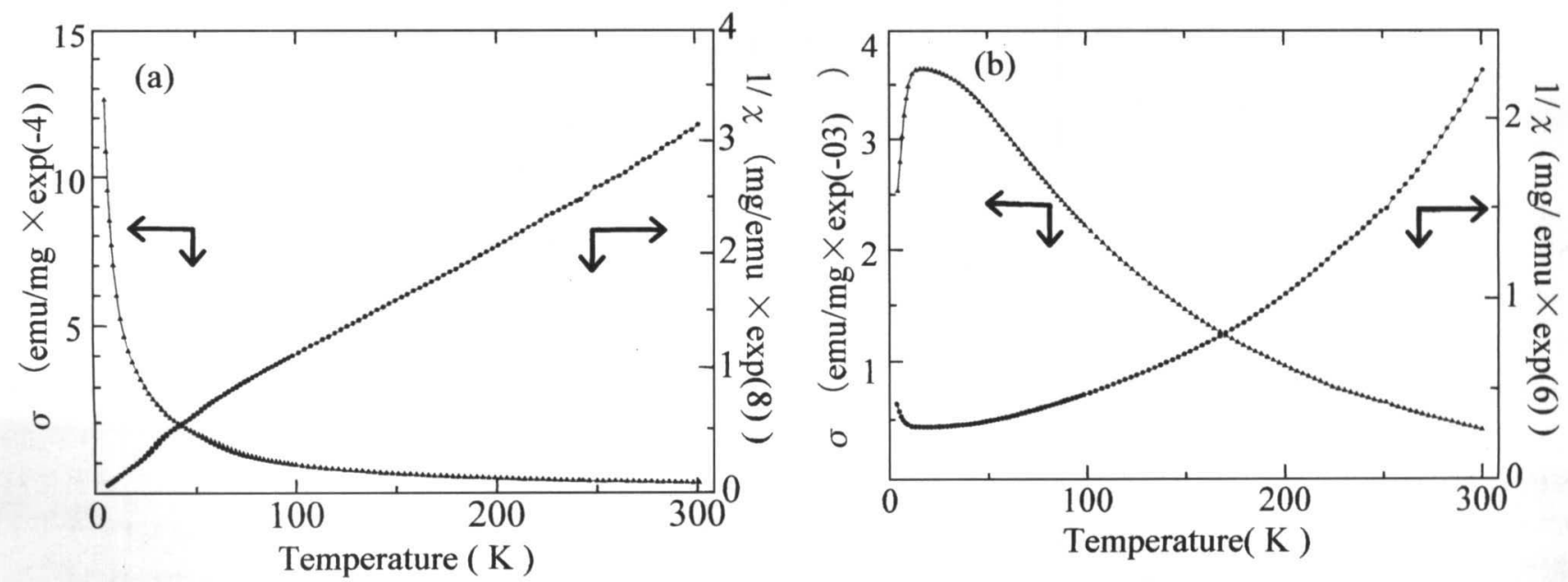

Fig.8(a), (b) (a) Magnetization and inverse magnetization curves of (a) $\mathrm{Bi}_{25} \mathrm{FeO}_{40}$ and (b) pseudo $\mathrm{Fe}$-sillenite $(\mathrm{Fe} / \mathrm{Bi}=50 \mathrm{~mole} \%$ ). 
極めて少量の $\mathrm{Fe}^{3+}$ イオンが $\mathrm{Bi}$ とOOマトリックス中に分散し ている結晶構造からも容易に予想され, またメスバウアース ペクトルが明瞭に観測されない, 言い換えれば Feの分量が少 ないため $\gamma$ 線の吸収が極めて悪いこととも一致している.こ れにたいしての擬-sillenite 相の磁化率は温度の低下とともに 増大するが〜 $16 \mathrm{~K}$ 近傍より再び減少しはじめ, 一見低次元の 反強磁性体のような挙動を示す. しかしながら擬 Fe-sillenite 相が, 観測されたXRDパターンから予想されるようなsillenite 構造 1 相の均一な化合物だとを仮定すると, 含有される $\mathrm{Fe}$ イ オンがこの結晶中で低次元のネットワークを構成することは 構造上から極めて考えにくい。これとは別に水溶液中で合成 される $\mathrm{Fe}$ の酸化物あるいはオキシ水酸化物は難溶性のため粒 子サイズが小さく, しばしば磁気的に超常磁性と呼ばれる挙 動を示すことが知られている.これらの実験結果を総合して 考えると, 擬 $\mathrm{Fe}$-sillenite は単相の化合物ではなく, むしろ $\mathrm{Bi}_{25} \mathrm{FeO}_{40}$ の組成を持つ数ミクロンのFe-silleneite粒子の表面に 無定形の微細な酸化鉄微粒子が薄く付着した, 極めて特異な 複合構造の沈殿粒子と考えられる.

\section{$3.2 \mathrm{Bi}_{25} \mathrm{FeO}_{40}$ (Fe-sillenite) 粒子の形状}

水溶液に対し溶解度が極めて低い化合物, 例えば酸化鉄に 代表されるような遷移金属酸化物などは, 水溶液を反応場と して合成すると結晶構造に対応した特有の粒子形状を示すこ とは広く知られている. 特有の粒子形状は反応場の条件が変 化しても, 多くの場合あまり変化しない.これに対してもう 少し高い溶解度を持つ化合物は, 同じ結晶構造であるが反応 条件に依存した複数の粒子形状を示す場合がある.

$\mathrm{Bi}_{25} \mathrm{FeO}_{40}$ の水溶液反応より生成した粒子の形状については これまで報告された例は見あたらない. 本報告では $\mathrm{Bi}_{25} \mathrm{FeO}_{40}$ の生成に影響を及ぼす因子を検討している中で，この化合物 は反応条件に依存した 2 種類の特有な形状を持つことを見い だした.一つはFig.9(a)によって示される立方体の形状を示す もので, 溶液中のアルカリ濃度が十分高い条件( $\mathrm{pH} 13$ 以上) 生成する.もう一つはFig.9(b)に示されるように, やゃアルカ
リ濃度の低い条件(pH12付近)生成し, 発達した三角形の面と それをつなぐ小さな面で形成され，おおまかな形状としては 四面体状を示す. 結晶構造より推測して, 立方体の面は(100) が, また四面体状の粒子の発達した三角形の面は(111)と考え られるが,どのような生成機構の差が粒子形状の違いをもたら すのかと共に現在まだ不明である.この特有の粒子形状は高温 顕微鏡を用いて大気下, in situで観測した結果, 融点 $\left(796^{\circ} \mathrm{C}\right)$ 直下まで出発時の状態を保っていることが判明した (Fig.10 (a1) (b2)).

3.3 擬 $\mathrm{Fe}$-sillenite 粒子を用いた $\mathrm{CO}_{2}$ の固定化

上記に述べたように, $\mathrm{Fe}$ と $\mathrm{Bi}$ の仕込みモル比が $3.8 \mathrm{~mole} \%$ 以上の場合に生成される擬Fe-sillenite相の沈澱は, sillenite構 造を持つ $\mathrm{Bi}_{25} \mathrm{FeO}_{40}$ 粒子の表面に無定形の酸化鉄の微粒子が面に付着している特異的な粒子形態を持っていると考えられ る. 言い換えれば $\mathrm{Bi}_{25} \mathrm{FeO}_{40}$ の $\mathrm{Bi}_{2} \mathrm{O}_{3}$ シートの上に無定形の酸 化鉄が担持された状態であり,なんらかの触媒作用が期待され る. 実際 $\alpha-\mathrm{Bi}_{2} \mathrm{O}_{3}$ は一定の条件下では $\mathrm{CO}_{2}$ と反応して, 炭酸 塩を形成する反応が知られているが, 本報告者等はこの反応 が擬Fe-sillenite粒子では著しく加速されることを見いだした. 一例として Fig.11(a),(b)に示すように, 仕込み量が Fe 48mole\% の擬 Fe-sillenite 粒子 (Fig.11(a)) では大気中, 室温の条件下で も, 大気中の $\mathrm{CO}_{2}$ を取り込み数力月の間にゆっくりと $\mathrm{Bi}_{2} \mathrm{O}_{2} \mathrm{CO}_{3}$ (Fig.11(b)) に変化する.XRD的にはFe酸化物のスペ クトルは反応の前後に於いて観測されないが,これは両状態 でFe酸化物がいずれも無定形状態をとっているためと考えら れる. 純粋の $\alpha-\mathrm{Bi}_{2} \mathrm{O}_{3}$ あるいは化学量論的な $\mathrm{Bi}_{25} \mathrm{FeO}_{40}$ を用い た場合, この反応は同等の反応条件下ではおこらないかある いは極めて反応速度が遅いため観測されない.一般にビスマ ス酸化物はヒトに対する毒性が極めて低く, 古くから薬用に 用いられている種類もある.このため擬 Fe-sillenite は環境に 優しい, 遅効性の大気中あるいは水溶液中の $\mathrm{CO}_{2}$ の固定化剂 としての用途が考えられる.

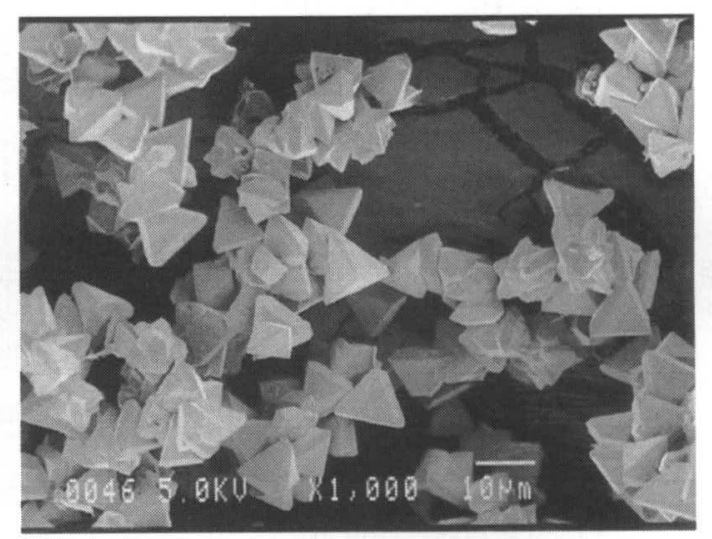

( b )

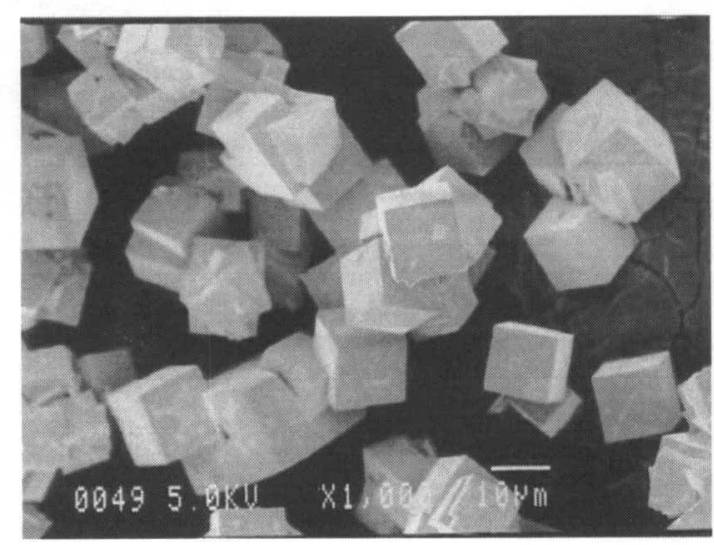

(a)

Fig.9 The two kind of particle shapes of $\mathrm{Bi}_{25} \mathrm{FeO}_{40}$, (a) the cubic-shaped particle precipitated at $\mathrm{pH}>13$, (b) the pyramidal-shaped particle
precipitated at $\mathrm{pH} \sim 12.0$. 


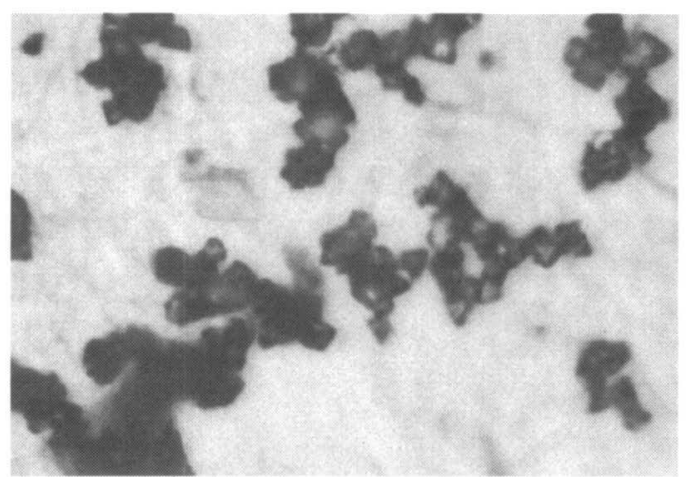

( a 1)

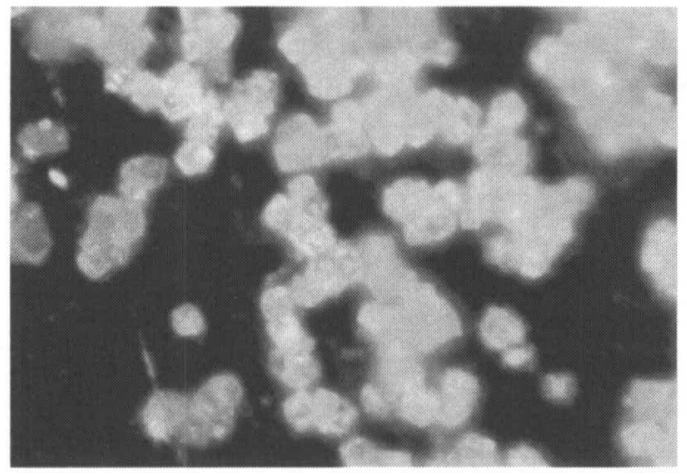

(b1)

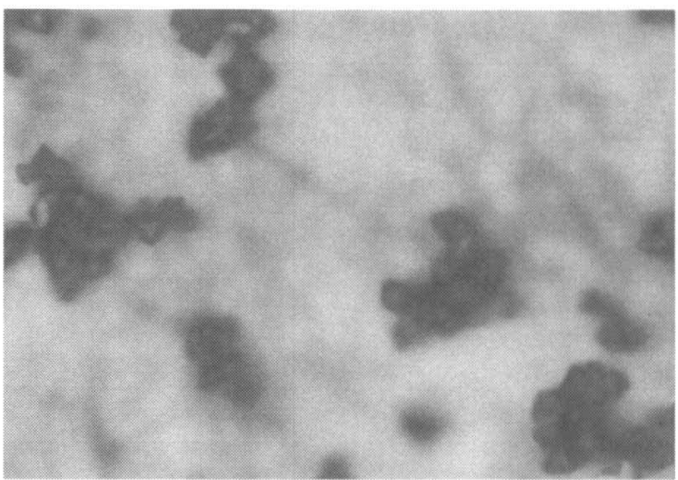

( a2)

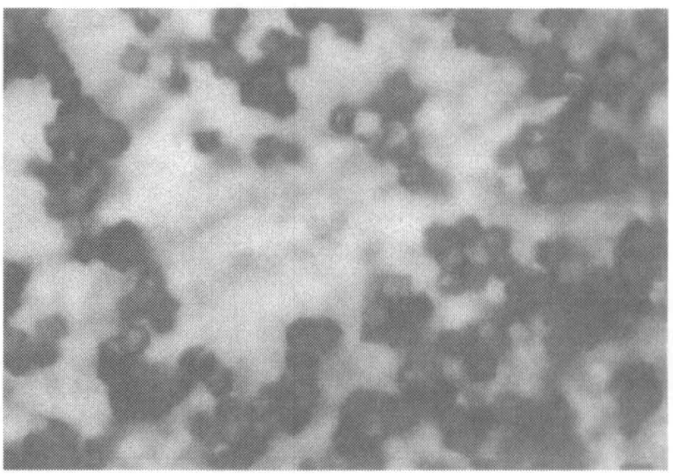

(b2)

Fig.10 The in situ observation of cubic-shaped particle and pyramidal-shaped particle at room temperature ((a1) and (b1), respectively) and just below the temperature of melting point $\left(796^{\circ} \mathrm{C}\right)((\mathrm{a} 2)$ and $(\mathrm{b} 2)$, respectively).

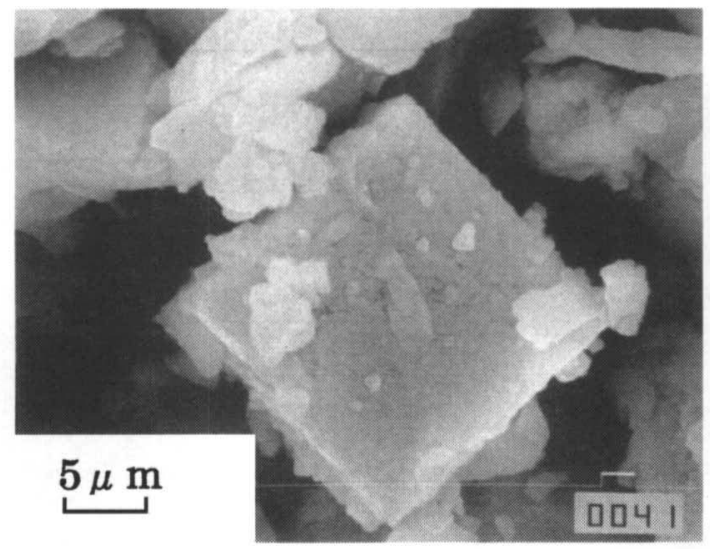

( a )

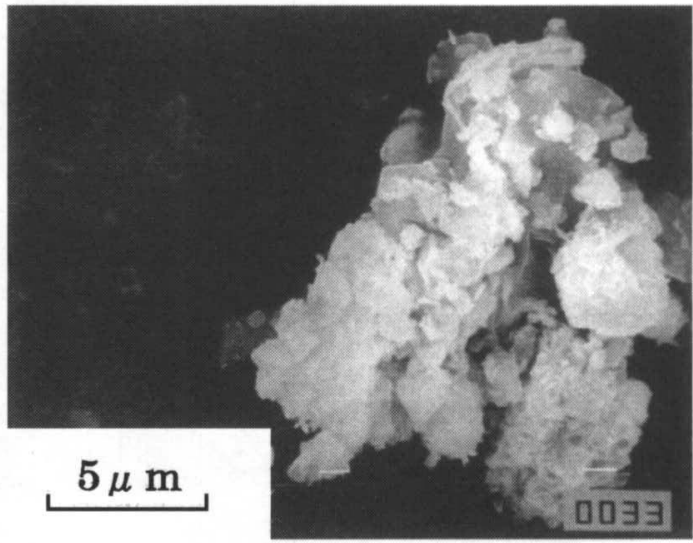

(b)

Fig.11 The SEM photograph of the (a) pseudo Fe-sillenite $(\mathrm{Fe} / \mathrm{Bi}=60$ mole $\%)$ and (b) converted $\mathrm{Bi}_{2} \mathrm{O}_{2} \mathrm{CO}_{3}$. The conversion took place at the room temperature in the air atomosphere.

\section{4 結 言}

(1) 水溶液を反応場とした $\mathrm{Bi}-\mathrm{Fe}-\mathrm{OH}^{-}$系の生成図が決定され た. 反応温度 $=30 \sim 600^{\circ} \mathrm{C} て ゙ は$ 端成分の $\alpha-\mathrm{Bi}_{2} \mathrm{O}_{3}$ と $\alpha-\mathrm{Fe}_{2} \mathrm{O}_{3}$ の他に $\mathrm{Bi}_{25} \mathrm{FeO}_{40}, \mathrm{BiFeO}_{3}$ および $\mathrm{Bi}_{2} \mathrm{Fe}_{4} \mathrm{O}_{9}$ の 3 相の生成が確 認された.

(2) 上記の反応で生成する $\mathrm{Bi}_{25} \mathrm{FeO}_{40}$ は数ミクロンの大きさを
もち, 生成条件に依存して立方体あるいは四面体の 2 種類 の粒子形状を示す。

(3) 上記の反応系で反応温度 $=30 \sim 100$, 仕込み時の $\mathrm{Fe} / \mathrm{Bi}$ の比 が 3.8 mole\% 以上の場合に生成する沈殿は, $\mathrm{Bi}_{25} \mathrm{FeO}_{40}$ 粒子 の表面が無定形の酸化鉄微粒子により覆われている特徵的 な形態を示し，極めて穞和な条件下に於いても大気中の 
$\mathrm{CO}_{2}$ ガス，溶存 $\mathrm{CO}_{2}$ あるいは $\mathrm{CO}_{3}{ }^{2-}$ と反応して $\mathrm{Bi}_{2} \mathrm{O}_{2} \mathrm{CO}_{3}$ へ 相変化することより, 遅效性の $\mathrm{CO}_{2}$ の固定化剂としての用 途が考えられる.

$$
\text { 文献 }
$$

1) E.M.Levin and R.S.J.Roth: "Polymorphism of Bismuth
Sequioxide. II. Effect of Oxide Additions on the Polymorphism of $\mathrm{Bi}_{2} \mathrm{O}_{3}{ }^{\prime \prime}, \mathrm{J}$. Research of National Bureau of Standards-A. Physics and Chemistry, 68A(2)(1964)197-206.

2) A.Ramahan and J.Gopalakrishnan: "Low-temperature Preparation of Sillenite Phases in $\mathrm{Bi}-\mathrm{M}-\mathrm{O}(\mathrm{M}=\mathrm{Mn}, \mathrm{Fe}, \mathrm{Co})$ System", Indian J. of Chemistry, 24(1985)594-596. 